\title{
Assessment of Hepatitis B Virus Infection and Associated Factors Among Pregnant Women Attending Antenatal Care Service in Bishoftu Town, South East, Ethiopia
}

\author{
Dagaga Kenea $^{1,}$, , Firaol Lemessa ${ }^{2}$ \\ ${ }^{1}$ Department of Medical Laboratory Sciences, College of Health Sciences, Arsi University, Asella, Ethiopia \\ ${ }^{2}$ Department of Public Health, College of Health Sciences, Arsi University, Asella, Ethiopia
}

Email address:

Dagagakenea@gmail.com (D. Kenea), fir12420@gmail.com (F. Lemessa)

${ }^{*}$ Corresponding author

To cite this article:

Dagaga Kenea, Firaol Lemessa. Assessment of Hepatitis B Virus Infection and Associated Factors Among Pregnant Women Attending Antenatal Care Service in Bishoftu Town, South East, Ethiopia. American Journal of Health Research. Vol. 8, No. 2, 2020 , pp. 11-17. doi: 10.11648/j.ajhr.20200802.12

Received: April 1, 2020; Accepted: April 21, 2020; Published: May 15, 2020

\begin{abstract}
Background: Hepatitis B virus infection is one of the serious public health problems in the world particularly in a developing country. It is transmitted from person to person by anybody fluid commonly through sexual intercourse. Hepatitis B virus infection has serious effects on both pregnant women and infants. Objective: This study aims to assess the magnitude of Hepatitis B virus infection and associated factors among pregnant women attending antenatal care service in Bishoftu town. Methods: A cross-sectional study was conducted involving a total of 276 pregnant women attending antenatal care service at Bishoftu town from July 17 - August 17, 2019. A systematic random sampling technique was used to select the study subjects. A blood sample was drawn from each study subject to testing for Hepatitis B surface antigen and confirmation for positive results was done by an enzyme-linked immune sorbent assay. Completed data from questionnaires were entered into Epi info version 7 and, exported and analyzed by SPSS Version 21. Descriptive statistics were carried out to estimate the characteristics of the participants. Bivariate and multivariate logistic regression analyses were used to identify factors associated with Hepatitis B virus infection. Odds ratios at $95 \%$ confidence interval were calculated. P-value $<0.05$ was considered as a significant. Result: The magnitude of Hepatitis B virus infection among pregnant women attending antenatal care services in Bishoftu town was $18(6.5 \%)$. Study subject with the previous history of the dental procedure [AOR=4.79, 95\%CI $(1.41$ $16.23)$ ], body tattooing $[\mathrm{AOR}=3.18,95 \% \mathrm{CI}(1.01-10.03)]$ and those with a multi-sexual partner [AOR $=5.19,95 \% \mathrm{CI}(1.09$ 24.60)] were known to have a significant association with Hepatitis B virus infection. Conclusion and Recommendation: This study indicates that Bishoftu town has intermediate endemicity of Hepatitis B virus infection among pregnant women. Regarding the risk factors, pregnant women with a dental procedure, body tattooing, and multi-sexual partner were found to be at risk of Hepatitis B virus infection. To minimize the higher risk exposure status of mothers, increasing awareness and public health education on the mode of Hepatitis B virus transmission, high-risk behaviors and methods of prevention are recommended.
\end{abstract}

Keywords: Hepatitis B Virus, Pregnant Women, Associated Factor

\section{Background}

Hepatitis B virus infection is a viral disease caused by Hepatitis B Virus (HBV) that causes acute and chronic liver disease and transmitted from person to person by any body fluids, but the most common method of transmission is through unsafe sexual intercourses $[1,2]$.
Worldwide, about 2 billion peoples are infected with HBV and more than 260,000 peoples are died due to HBV infection each year. Approximately, 5 million peoples are living with chronic HBV infections in Ethiopia [2].

Hepatitis B viral infections in pregnancy are the most common cause of morbidity and mortality for both mother and fetus [3]. Presence of $\mathrm{HBV}$ infection in early life 
increases the risk of chronic liver disease, the development of cirrhosis, splenomegaly and hepatocellular carcinoma and Also, it may cause maternal complication and infant death by impaired mental and physical health $[3,4]$.

Pregnant women are more susceptible to certain pathogens including viruses, intracellular bacteria and parasites due to immunologic changes.

The predominant mode of $\mathrm{HBV}$ transmission in endemic areas is mother-to-child transmission also known as perinatal transmission [5]. Infected pregnant mothers have a $10-20 \%$ chance of transmitting the virus to their babies [6].

The risk factors of HBV infection for pregnant women depend on cultural practices and beliefs [6]. Indicated by different studies, the risk factors of $\mathrm{HBV}$ infections are linked to exposure of infected body fluids, occupational exposure, multiple-sexual partner, blood transfusion, body tattooing, history of surgery, unsafe injection, history of abortion, transmission from mother to infants and traditional practices like scarification and ear piercing [6]. The exposure of HBV transmission reduces in an area where there is a periodic perinatal HBV screening, hepatitis $\mathrm{B}$ vaccine administered to both high-risk mothers and all newborn infants born from infected mothers [7]. In Ethiopia, to prevent mother-to-child transmission of HBV the expanded program on immunization was launched in 1980 to increase the coverage by $10 \%$ annually [4].

However, information from the different study showed that the magnitude of $\mathrm{HBV}$ infection and predictors of $\mathrm{HBV}$ infection was different from region to region. Moreover, there is no known level of HBV infection and the risk of breakthrough infection among pregnant mothers in Bishoftu town.

The present study was intended to assess the magnitude of HBV infection and associated factors among pregnant women attending antenatal care services in Bishoftu town, Ethiopia.

\section{Methods}

\subsection{Study Area and Period}

The study was conducted at Bishoftu town. It is $47 \mathrm{~km}$ away from Addis Ababa in the southeast of Ethiopia. The town has a latitude and longitude of $8^{\circ} 45^{\prime} 8.10^{\prime \prime} \mathrm{N}$ and $38^{\circ}$ $58^{\prime} 42.46^{\prime \prime}$ respectively with an elevation of 1,920 meters above sea levels. The total population of the town is estimated to be around 167,318 (42). Bishoftu town has 1 government hospital, 4 health centers and 2 private higher clinics that are giving full antenatal care (ANC), delivery and postnatal care (PNC) services. The total number of the eligible population in the town for $\mathrm{ANC}$, delivery and postnatal care was around 1138 /month based on the previous registered annual number of clients [8].

The cross-sectional study design was employed from July 17 - August 17, 2019, among pregnant women who visited the study area.

\subsection{Source and Study Population}

All pregnant women in Bishoftu town were used as a source of population and all pregnant women attending ANC clinic for check-up service in selected health facilities during the study period.

\subsection{Sample Size and Sampling Technique}

The sample size was calculated using a single population proportion formula by considering the proportion of Hepatitis $\mathrm{B}$ virus infection risk of $6.3 \%$ from a study done in Harar city [9], and a $3 \%$ margin of error with $10 \%$ non-response was used.

$$
\mathrm{n}=(Z \alpha / 2)^{2} \mathrm{P}(1-\mathrm{P}) / \mathrm{d}^{2}
$$

Where: $n=$ Sample size required $\mathrm{Z} \alpha / 2=95 \%$ confidence level (1.96)

$\mathrm{P}=$ Proportion of $\mathrm{HBV}$ infection (0.063) $\mathrm{d}=$ Desired precision (3\%)

Accordingly, a total of 276 study participants were included.

The study participants were enrolled from the randomly selected 1 hospital, 3 health centers, and 1 private clinic. To select sample size from the selected health facilities, proportional allocations were done for each health facilities and a systematic random sampling technique was used to select a total of 276 study participants from selected health facilities (Figure 1).

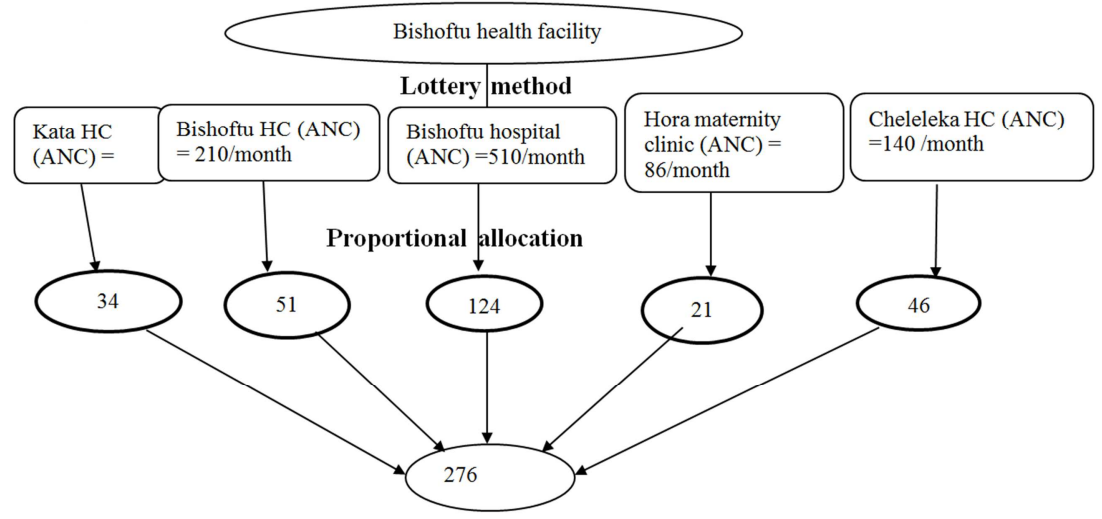

Figure 1. Schematic representation of the sampling procedure. 


\subsection{Data Collection Procedures}

A structured questionnaire was originally developed in English by reviewing different kinds of literature and translated into Afaan Oromo and then back-translated to English for consistency. The questionnaire was pre-tested outside of the study area for clarity and consistency. After a brief explanation about the aim of the study, the participants were requested to take part in the study voluntarily and also informed about $4 \mathrm{ml}$ of blood will be drawn to determine their Hepatitis B serostatus.

After the written consent was accepted the data collector was conducted the interview followed by coding and transferring of the subjects to the laboratory, then trained laboratory technologist was collect the blood sample.

Pregnant mothers willing to participate were included in this study and Pregnant mothers who need urgent management, unwilling and mentally ill mothers during the study period were excluded from this study.

\subsection{Blood Collection and Processing}

Whole blood was drawn from a study subject after a written consent form was taken. During specimen collection $4 \mathrm{ml}$ of blood was collected aseptically in serum separated tube, using SOP in each health facility then sample kept for about 30 minutes at room temperature for natural clotting to take place then serum was separated from whole blood at $3000 \mathrm{rpm}$ for 5 minutes using an electric centrifuge.

\subsection{Laboratory Testing for HBsAg and Storage of Serum}

After the serum sample was separated from whole blood it is immediately tested using the HBsAg test kit. The membrane test kit was pre-coated with anti-HBsAg antibodies on the test band region and anti-mouse antibodies on the control band region. During testing the serum sample reacts with the dye conjugate (mouse anti-HBsAg antibody colloidal gold conjugate) that was coated in the test strip. The mixture than by capillary action reacts with anti-HBsAg antibodies on the membrane and generates a red band. The result was read after $20 \mathrm{~min}$.

Positive if the colored line appears on both the test region and the control region. Negative if only one colored line appears on control regions. Invalid if no colored line at the control region. The leftover serum samples were stored at $20^{\circ} \mathrm{C}$.

The positive result was confirmed by an enzyme-linked immune sorbent assay (ELISA) test by transporting serum to National Blood Bank using a cold box.

\subsection{Data Quality Control}

The questionnaire was pretested at the health institution other than the actual study sites on $5 \%$ of sampled pregnant women. The training was given for the data collectors and laboratory technologists responsible for processing the sample.
The data collectors were supervised by the principal investigator daily and, the validity and completeness of the data were verified by the principal investigator daily. Specimen collection, labeling, processing, storage, and testing were by the standard operating procedures of the laboratories and according to the manufacturer's recommendation. The performance of the rapid HBsAg test kit was evaluated using known positive and negative controls obtained from the ELISA-tested sample. Furthermore, the formation of a colored band at the control line acted as a procedural control and further validated the results. Similarly, ELISA test results were also assured using positive and negative controls according to the manufacturer's manual.

\subsection{Data Processing and Analysis}

Completed data was entered into a computer using Epi version -7. Then data was exported into SPSS version -21 statistical software followed by data cleaning and analysis. Descriptive analyses were used to estimate the magnitude of HBV infection and the characteristics of participants. Binary logistic regression analysis was used to identify the association between explanatory variables and the outcome variable. Odds ratio (OR) at $95 \%$ confidence intervals (CI) were calculated and the association was considered statistically significant at $p<0.05$. Finally, the goodness of fit of the final model was checked using Hosmer and Lemeshow statistics.

\subsection{Ethical Consideration}

The study was conducted after obtaining ethical clearance from the Ethical Review Committee of Arsi University college of health science. Official letter of support was obtained from the Ethical Review Committee of Oromia Regional State Health Bureau and Bishoftu town health office. Written informed consent was also obtained from each study participant. HBsAg positive result was reported to physicians and/or health officers for further diagnosis and management. Information on any course of the study was kept confidentially using code number and each participant was interviewed in private to promote confidentiality. Besides, the clinical specimen collected during the study period was used only for the stated objectives.

\section{Result}

\subsection{Socio-demographic Characteristics}

In this study, a total of 276 pregnant women were included. The overall mean age was $25.4 \pm 6.5$ years, within the range of 18-35 years of age. The majority of the respondents, $218(79.0 \%)$ were within the age category of 25 - 29 years. Among the participant, $38.8 \%$ of them were house wife's, $45.3 \%$ were Oromo and most, $90.9 \%$ of them were married (Table 1). 
Table 1. Socio-demographic characteristics of pregnant women attending ANC service in selected health facilities of Bishoftu town, Southeast of Ethiopia, from July 17 - August 17, 2019.

\begin{tabular}{|c|c|c|c|}
\hline Characteristics & Category & $\begin{array}{l}\text { Frequency } \\
\text { (n) }\end{array}$ & $\begin{array}{l}\text { Percent } \\
(\%)\end{array}$ \\
\hline \multirow{4}{*}{ Age (in a year) } & $<20$ & 10 & 3.6 \\
\hline & $21-24$ & 35 & 12.7 \\
\hline & $25-29$ & 218 & 79.0 \\
\hline & $>30$ & 13 & 4.7 \\
\hline \multirow{4}{*}{ Ethnicity } & Oromo & 125 & 45.3 \\
\hline & Amhara & 101 & 36.6 \\
\hline & Gurgae & 19 & 6.9 \\
\hline & Others & 31 & 11.2 \\
\hline \multirow{7}{*}{$\begin{array}{l}\text { Educational } \\
\text { status } \\
\text { Marital status }\end{array}$} & Not educated & 35 & 12.7 \\
\hline & Primary (1-8) & 100 & 36.2 \\
\hline & Secondary (9-12) & 81 & 29.3 \\
\hline & Diploma and above & 60 & 21.7 \\
\hline & Married monogamous & 251 & 90.9 \\
\hline & Married polygamous & 6 & 2.2 \\
\hline & Others & 19 & 6.9 \\
\hline \multirow{5}{*}{$\begin{array}{l}\text { Occupational } \\
\text { status }\end{array}$} & Student & 12 & 4.3 \\
\hline & Health professionals & 12 & 4.3 \\
\hline & Housewife & 107 & 38.8 \\
\hline & Government employee & 47 & 17.0 \\
\hline & Private employee & 98 & 35.5 \\
\hline \multirow{3}{*}{$\begin{array}{l}\text { Monthly } \\
\text { income } \\
\text { (in Eth. Birr) }\end{array}$} & $<1000$ & 143 & 51.8 \\
\hline & $1000-2000$ & 75 & 27.2 \\
\hline & $>2000$ & 58 & 21.0 \\
\hline
\end{tabular}

\subsection{The Magnitude of Hepatitis B Virus Infection}

Out of the total 276 study participants, whose serum samples were tested for HBsAg, only 18 (6.5\%) study participants were positive. To decrease false positivity, all positive serum samples were confirmed by ELISA tests. However, all $18(6.5 \%)$ positive serum samples were also positive for ELSA tests (Figure 2).

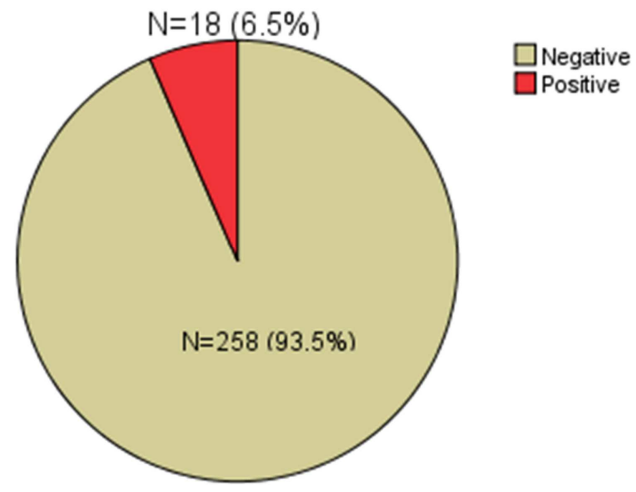

Figure 2. The magnitude of Hepatitis $B$ virus infection among pregnant women attending ANC service in selected health facilities of Bishoftu town, Southeast of Ethiopia, from July 17 - August 17, 2019.

From a total of the sample tested for HBV infection. At least one hepatitis positive result was observed in each age group and in every education category. However, the highest magnitude was observed in 21-24 age groups $4(11.4 \%)$ and who had secondary education 7 (8.6\%). Although, housewife $9(8.4 \%)$ and married polygamous participants $16.7 \%$ had more HBV positive results. Regarding possible risk factors practice by study subjects, $38(13.8 \%)$ had the previous history of a dental procedure and 7 (18.4\%) of them were positive for the HBV test. Among 54 (19.6\%) pregnant women had a tattoo on their body, 7 (13.0\%) of them were positive for the HBV test. Concerning other risk practices by respondents 18 (6.5) had multiple sexual partners from this 4 (21.1) pregnant women were positive for HBV test (Table 2).

Table 2. The magnitude of HBV infection among pregnant women attending ANC service in selected health facilities of Bishoftu town, Southeast of Ethiopia, from July 17 - August 17, 2019.

\begin{tabular}{|c|c|c|c|}
\hline \multirow[b]{2}{*}{ Characteristics } & \multirow[b]{2}{*}{ Category } & \multicolumn{2}{|c|}{ HBV Status } \\
\hline & & $\begin{array}{l}\text { Positive } \\
\text { n (\%) }\end{array}$ & $\begin{array}{l}\text { Negative } \\
\text { n (\%) }\end{array}$ \\
\hline \multirow{4}{*}{ Age (in year) } & $<20$ & $1(10)$ & $9(90)$ \\
\hline & $21-24$ & $4(11.4)$ & $31(88.6)$ \\
\hline & $25-29$ & $12(5.5)$ & $206(94.5)$ \\
\hline & $>30$ & $1(7.7)$ & $12(92.3)$ \\
\hline \multirow{4}{*}{ Ethnicity } & Oromo & $5(4.0)$ & $120(96.0)$ \\
\hline & Amhara & $7(6.9)$ & $94(93.1)$ \\
\hline & Gurgae & $2(10.5)$ & $17(89.5)$ \\
\hline & Others & $4(12.9)$ & $27(87.1)$ \\
\hline \multirow{7}{*}{$\begin{array}{l}\text { Educational status } \\
\text { Marital status }\end{array}$} & Not educated & $2(5.7)$ & $33(94.3)$ \\
\hline & Primary (1-8) & $4(4)$ & $96(96)$ \\
\hline & Secondary (9-12) & $7(8.6)$ & $74(91.4)$ \\
\hline & Diploma and above & $5(8.3)$ & $55(91.7)$ \\
\hline & Married monogamous & $14(5.6)$ & $237(94.4)$ \\
\hline & Married Polygamous & $1(16.7)$ & $5(83.3)$ \\
\hline & Others & $3(15.8)$ & $16(84.2)$ \\
\hline \multirow{5}{*}{ Occupational status } & Student & $1(8.3)$ & $11(91.7)$ \\
\hline & Health professionals & $1(8.3)$ & $11(91.7)$ \\
\hline & Housewife & $9(8.4)$ & 98 (91.6) \\
\hline & Government employee & $2(4.3)$ & 45 (95.7) \\
\hline & Private employee & $5(5.1)$ & $93(94.9)$ \\
\hline \multirow{3}{*}{$\begin{array}{l}\text { Monthly income } \\
\text { (in Eth. Birr) }\end{array}$} & $<1000$ & $11(7.7)$ & $132(96.3)$ \\
\hline & $1000-2000$ & $5(6.7)$ & $70(93.3)$ \\
\hline & $>2000$ & $2(3.4)$ & $56(96.6)$ \\
\hline \multirow{2}{*}{$\begin{array}{l}\text { History of hospital } \\
\text { admission }\end{array}$} & Yes & $5(15.6)$ & $27(84.4)$ \\
\hline & No & $13(5.3)$ & $231(94.7)$ \\
\hline \multirow{2}{*}{$\begin{array}{l}\text { History of dental } \\
\text { procedure }\end{array}$} & Yes & $7(18.4)$ & $31(81.6)$ \\
\hline & No & $11(4.6)$ & $227(95.4)$ \\
\hline \multirow{2}{*}{ History of surgery } & Yes & $1(10.0)$ & $9(90.0)$ \\
\hline & No & $17(6.4)$ & $249(93.6)$ \\
\hline \multirow{2}{*}{ History of abortion } & Yes & $2(7.7)$ & $24(92.3)$ \\
\hline & No & $16(6.4)$ & $234(93.6)$ \\
\hline \multirow{2}{*}{ Tattooing } & Yes & $7(13.0)$ & $47(87.0)$ \\
\hline & No & $11(5.0)$ & $211(95.0)$ \\
\hline \multirow{2}{*}{ Ear piercing } & Yes & $14(5.9)$ & $225(94.1)$ \\
\hline & No & $4(10.8)$ & $33(89.2)$ \\
\hline \multirow{2}{*}{ Nose piercing } & Yes & 0 & $6(100)$ \\
\hline & No & $18(6.7)$ & $252(93.3)$ \\
\hline \multirow{2}{*}{$\begin{array}{l}\text { History of blood } \\
\text { transfusion }\end{array}$} & Yes & $1(14.3)$ & $6(85.7)$ \\
\hline & No & $17(6.3)$ & $252(93.7)$ \\
\hline \multirow{2}{*}{ History of family } & Yes & 0 & $4(100)$ \\
\hline & No & $18(6.6)$ & $254(93.4)$ \\
\hline \multirow{2}{*}{ Multi sexual partner } & Yes & $4(21.1))$ & $14(5.4)$ \\
\hline & No & 15 (78.9) & $243(94.6)$ \\
\hline
\end{tabular}




\subsection{Factors Associated with Hepatitis B Virus Infection}

Results of logistic regression analysis indicated that few predictor variables showed statistically significant association with HBV infection. Following the bivariate logistic regression analysis (considering $p$-value $<0.25$ ), the multivariate analysis was made. Accordingly, pregnant women with the previous history of the dental procedure $[\mathrm{AOR}=4.79, \quad 95 \% \mathrm{CI} \quad(1.41-16.23)], \quad$ body tattooing [AOR $=3.18,95 \% \mathrm{CI} \quad(1.01-10.03)]$ and multiple sexual partners $[\mathrm{AOR}=5.19,95 \% \mathrm{CI}(1.09-24.60)]$ were statistically associated with HBV infection (Table 3).

Table 3. Bivariate and multivariate analysis of associated factors with HBV infection among pregnant women attending ANC service in selected health facility of Bishoftu town, Southeast of Ethiopia, from July 17 - August 17, 2019.

\begin{tabular}{|c|c|c|c|c|}
\hline \multirow{2}{*}{ Characteristics } & \multicolumn{2}{|l|}{ HBV status } & \multirow{2}{*}{ COR $(95 \% C I)$} & \multirow{2}{*}{ AOR (95\%CI) } \\
\hline & Positive N (\%) & Negative $\mathbf{N}(\%)$ & & \\
\hline \multicolumn{5}{|l|}{ Age } \\
\hline$<20$ & $1(10)$ & $9(90)$ & 1 & 1 \\
\hline $21-24$ & $4(11.4)$ & $31(88.6$ & $1.16(0.12-11.74)$ & $1.20(0.08-19.32)$ \\
\hline $25-29$ & $12(5.5)$ & $206(94.5)$ & $0.52(0.61-04.48)$ & $0.42(0.04-5.08)$ \\
\hline$>30$ & $1(7.7)$ & $12(92.3)$ & $0.75(0.04-13.68)$ & $0.27(0.01-7.86)$ \\
\hline \multicolumn{5}{|l|}{ Marital status } \\
\hline Married monogamous & $14(5.6)$ & $237(94.4)$ & 1 & 1 \\
\hline Married polygamous & $1(16.7)$ & $5(83.3)$ & $3.38(0.37-30.98)$ & $3.33(0.24-35.27)$ \\
\hline Others & $3(15.8)$ & $16(84.2)$ & $3.17(0.83-12.19)$ & $2.47(0.47-12.75)$ \\
\hline \multicolumn{5}{|l|}{ Occupational status } \\
\hline Student & $1(8.3)$ & $11(91.7)$ & 1 & 1 \\
\hline Health professionals & $1(8.3)$ & $11(91.7)$ & $1.00(0.55-18.08)$ & $4.42(0.12-60.33)$ \\
\hline Housewife & $9(8.4)$ & 98 (91.6) & $1.01(0.11-8.08)$ & $3.42(0.19-42.27)$ \\
\hline Government employee & $2(4.3)$ & $45(95.7)$ & $0.49(0.04-5.89)$ & $2.09(0.86-31.03$ \\
\hline Private employee & $5(5.1)$ & $93(94.9)$ & $0.59(0.06-5.53)$ & $1.52(0.08-12.58)$ \\
\hline \multicolumn{5}{|c|}{ History of hospital admission } \\
\hline Yes & $5(15.6)$ & $27(84.4)$ & \multirow{2}{*}{$3.29(1.09-9.94)$} & \multirow{2}{*}{$3.19(0.981-12.58)$} \\
\hline No & $13(5.3)$ & $231(94.7)$ & & \\
\hline \multicolumn{5}{|c|}{ History of dental procedure } \\
\hline Yes & $7(18.4)$ & $31(81.6)$ & \multirow{2}{*}{$4.66(1.68-12.81)$} & \multirow{2}{*}{$4.79(1.41-16.23)$} \\
\hline No & $11(4.6)$ & $227(95.4)$ & & \\
\hline \multicolumn{5}{|l|}{ History of surgical } \\
\hline Yes & $1(10.0)$ & $9(90.0)$ & \multirow{2}{*}{$1.63(0.19-13.60)$} & \multirow{2}{*}{$0.77(0.05-10.92)$} \\
\hline No & $17(6.4)$ & $249(93.6)$ & & \\
\hline \multicolumn{5}{|l|}{ Ear piercing } \\
\hline Yes & $14(5.9)$ & $225(94.1)$ & \multirow{2}{*}{$0.51(0.16-1.62)$} & \multirow{2}{*}{$0.40(0.10-1.57)$} \\
\hline No & $4(10.8)$ & $33(89.2)$ & & \\
\hline \multicolumn{5}{|l|}{ Tattooing } \\
\hline Yes & $7(13.0)$ & $47(87.0)$ & \multirow{2}{*}{$2.86(1.05-7.76)$} & \multirow{2}{*}{$3.18(1.01-10.03)$} \\
\hline No & $11(5.0)$ & $211(95.0)$ & & \\
\hline \multicolumn{5}{|l|}{ History blood transfusion } \\
\hline Yes & $1(14.3)$ & $6(85.7)$ & \multirow{2}{*}{$2.47(0.28-21.71)$} & \multirow{2}{*}{$3.36(0.24-26.56)$} \\
\hline No & $17(6.3)$ & $252(93.7)$ & & \\
\hline \multicolumn{5}{|l|}{ Multi sexual partner } \\
\hline Yes & $4(21.1))$ & $14(5.4)$ & \multirow{2}{*}{$4.63(1.36-15.79)$} & \multirow{2}{*}{$5.19(1.09-24.60)$} \\
\hline No & $15(78.9)$ & $243(94.6)$ & & \\
\hline
\end{tabular}

$\mathrm{AOR}=$ Adjusted odds ratio; $\mathrm{COR}=\mathrm{Crude}$ odds ratio; $1=$ Reference value; $\mathrm{N}=$ Number.

\section{Discussion}

From this study, the magnitude of HBV infection among pregnant women attending ANC services in Bishoftu health institutions were $18(6.5 \%)$. According to the WHO classification, the magnitude of HBV infection in the study area can be categorized as intermediate endemicity ( $2 \%$ $7 \%$ [2]. The magnitude of HBV infection was nearly similar to the result reported in Addis Ababa, Harar city,
Deder, and Jigiga as $6 \%, 6.3 \%, 6.9 \%$, and $6 \%$, respectively $[2,9-11]$. The result of this study was relatively higher when compared with the result reported from Addis Ababa 3\% [12], Arba Minch hospital 4.3\% [13], Felege Hiwot referral hospital 4.4\% [14] and Bahir dar city 3.8\% [15]. However, the magnitude of this study was $(6.5 \%)$ lower than the result reported from Hawassa (7.8\%) [16]. The variations might be because of differences in geographical regions, cultural practices, the strategy used for nosocomial 
infection prevention and practice of risk behaviors.

In comparison with the finding in different African countries, the magnitude of HBV infection among pregnant women was higher than the result reported from Egypt (4\%) [17], Uganda (0.9\%) [18], Rwanda (3.1\%) [19] and Ghana $(2.4 \%)$ [20]. However, the finding of this study was lower when compared with the result reported from Cameron (9.7\%) [21], Nigeria (7.9\%) [22] and South Sudan (11\%) [23]. The variations might be because of differences in geographical regions, socio-demographic variations between countries, economic status, differences in cultural practices and risk behavior towards the risk of $\mathrm{HBV}$ infection. Furthermore, the variation might be due to laboratory testing algorithms and methods, sample size, study period and study design. In comparison with developed countries, the result of this study is higher than result reported from USA, except Asian Americans (0.14\%- 0.97\%) [11], Brazil (0.9\%) [24], Mexico (1.65\%) [25], and Saudi Arabia (1.6\%) [26]. This difference might be due to regular screening and vaccination provided in developed countries.

This study showed that previous history of dental procedure was the risk factor of HBV infection. Pregnant women with the previous history of dental procedure had a chance of 4.79 times [AOR $=4.79,95 \% \mathrm{CI}(1.41-16.23)$ ], to develop HBV infection when compared with pregnant women who had no previous history of the dental procedure. This finding was similar to the study conducted in Jigjiga [11], Harar city [9], and Jimma town [16]. However, this study was inconsistent with studies conducted in Addis Ababa [12], Deder hospital [2] and Bahir dar city [15]. In comparison with an African country, the result of this study was similar to a study conducted in Abia states; Nigeria among pregnant women revealed that history of dental procedure was statistically significant with $\mathrm{HBV}$ infection [15]. However, this study was inconsistent with studies conducted in Nigeria [22], the Republic of South Sudan [23] and Uganda [18]. Overall, the discrepancy might be due to non-adherence to guidelines on infection control and reusable equipment and the lack of sufficient sterilization technology.

In this study, pregnant women with multiple sexual partners had a chance of 5.19 times [AOR=5.19, 95\%CI (1.09-24.60)] to develop $\mathrm{HBV}$ infection when compared with pregnant women who had no multi-sexual partner. The finding of this study is similar to studies conducted in Addis Ababa [12], Deder Hospital [2] and Hawassa [16]. However, this study was inconsistent with studies conducted in Jigjiga [11], Harar city [9], Bahir dar [15] and Jimma town [16]. In comparison with African countries, a study conducted in Abia state; Nigeria showed that pregnant women with a history of multiple sexual partners were significantly associated with HBV infection [27]. However, studies conducted in Rwanda [27], Uganda [18], and Nigeria [22] were unlike the result of this study. In a developed country, the study carried out in Saudi Arabia [28] showed that a history of multiple sexual partners had no significant association with $\mathrm{HBV}$ infection. The difference might be due to unprotected sexual intercourse.

Concerning body tattooing, pregnant women who had a tattoo on their body had a chance of 3.18 times $[\mathrm{AOR}=3.18$, 95\%CI (1.01-10.03)] to develop HBV infection when compared with pregnant women who had no tattoo on their body. The result of this study was similar to the study conducted in Bahir dar city and Gondar [15, 29]. Also, it was similar to a study conducted in Nigeria [22]. However, this study was inconsistent with studies conducted in Addis Ababa [12], Deder hospital and Jimma [6]. The discrepancy might be due to socio-cultural and behavior practice toward the population and lack of safety precautions being taken.

\section{Conclusion and Recommendations}

The overall magnitude of HBV infection among pregnant women in Bishoftu town is an intermediate $(6.5 \%)$ endemic area according to the WHO classification criteria. This study suggests that factors such as the previous history of dental procedure, body tattooing and history of multiple sexual partners were the risk factors of HBV infection. To minimize the higher risk exposure status of mothers, increasing awareness and public health education on the mode of Hepatitis B virus transmission, high-risk behaviors and methods of prevention are recommended.

\section{Acknowledgements}

We would like to acknowledge the Arsi University department of public health and Medical laboratory Science for allowing conducting this study. Selected health facilities and National Blood Bank workers deserve acknowledgment for their unlimited support during data collection, sample collection and for the confirmatory ELISA testing respectively. Last, but not least, our appreciation also goes to the study participants.

\section{References}

[1] Hou, J., Z. Liu, and F. Gu, Epidemiology and prevention of hepatitis $B$ virus infection. International journal of medical sciences, 2005. 2 (1): p. 50.

[2] Umare, A., et al., Hepatitis B virus infections and associated factors among pregnant women attending antenatal care clinic at Deder Hospital, Eastern Ethiopia. PLoS One, 2016. $11(11)$.

[3] Singhal, P., S. Naswa, and Y. Marfatia, Pregnancy and sexually transmitted viral infections. Indian journal of sexually transmitted diseases and AIDS, 2009. 30 (2): p. 71.

[4] Chernet, A., A. Yesuf, and A. Alagaw, Seroprevalence of hepatitis $B$ virus surface antigen and factors associated among pregnant women in the Dawuro zone, SNNPR, Southwest Ethiopia: a cross-sectional study. BMC research notes, 2017. 10 (1): p. 418.

[5] Getahun, A., et al., Seroprevalence of hepatitis B surface antigen in pregnant women attending antenatal clinic in Honiara Solomon Islands, 2015. World journal of hepatology, 2016. 8 (34): p. 1521. 
[6] Awole, M. and S. Gebre-Selassie, Seroprevalence of HBsAg and its risk factors among pregnant women in Jimma, Southwest Ethiopia. Ethiopian Journal of Health Development, 2005. 19 (1): p. 45-50.

[7] Stewart, R. D. and J. S. Sheffield, Hepatitis B Vaccination in Pregnancy in the United States. Vaccines, 2013. 1 (2): p. 167-173.

[8] Endalkachew, A., Assessment of Municipal Solid Waste Management Practices: A Case Study of Bishoftu City Administration. 2018, AAU.

[9] Tiruye, G., K. Shiferaw, and F. Tadesse, Seroprevalence of hepatitis $B$ virus infection and associated factors among pregnant women attended antenatal care services in Harar City, Eastern Ethiopia. J Women's Health Care, 2018. 7 (436): p. 2167-0420.1000436.

[10] Desalegn, Z., et al., Hepatitis B and human immunodeficiency virus co-infection among pregnant women in a resourcelimited high endemic setting, Addis Ababa, Ethiopia: implications for prevention and control measures. European journal of medical research, 2016. 21 (1): p. 16.

[11] Mirambo, M. M., et al., Prevalence of Hepatitis B surface antigen among pregnant women attending antenatal clinic at Nyamagana District Hospital Mwanza, Tanzania. Tanzania Journal of Health Research, 2016. 18 (1).

[12] Tegegne, D., et al., Seroprevalence and transmission of Hepatitis $B$ virus among delivering women and they're newborn in selected health facilities, Addis Ababa, Ethiopia: a cross-sectional study. BMC research notes, 2014.7 (1): p. 239.

[13] Yohanes, T., Z. Zerdo, and N. Chufamo, Seroprevalence and predictors of hepatitis $B$ virus infection among pregnant women attending routine antenatal care in Arba Minch Hospital, South Ethiopia. Hepatitis research and treatment, 2016.

[14] Molla, S., A. Munshea, and E. Nibret, Seroprevalence of hepatitis $B$ surface antigen and anti $\mathrm{HCV}$ antibody and its associated risk factors among pregnant women attending maternity ward of Felege Hiwot Referral Hospital, northwest Ethiopia: a cross-sectional study. Virology journal, 2015. 12 (1): p. 204.

[15] Zenebe, Y., et al., Sero-prevalence and risk factors of hepatitis $B$ virus and human immunodeficiency virus infection among pregnant women in Bahir Dar city, Northwest Ethiopia: a cross-sectional study. BMC infectious diseases, 2014. 14 (1): p. 118.

[16] Metaferia, Y., et al., Seroprevalence and associated risk factors of hepatitis $B$ virus among pregnant women in southern Ethiopia: a hospital-based cross-sectional study. Epidemiology and health, 2016. 38.

[17] Zahran, K. M., et al., Pattern of hepatitis virus infection among pregnant women and their newborns at the Women's
Health Center of Assiut University, Upper Egypt. International Journal of Gynecology \& Obstetrics, 2010. 111 (2): p. 171174.

[18] Allen, N., M. Bashir, and T. I. Mugisha, Prevalence and Associated Factors of Hepatitis B Virus Infection among Pregnant Women Attending Antenatal Care Clinic at Mulago National Referral Hospital, Uganda. International Blood Research \& Reviews, 2017: p. 1-10.

[19] Nyamusi, M. M., et al., Factors associated with hepatitis $B$ surface antigen seropositivity among pregnant women in Kigali, Rwanda: A Cross-Sectional Study. 2017.

[20] Luuse, A., et al., Sero-prevalence of hepatitis B surface antigen amongst pregnant women attending an antenatal clinic, Volta region, Ghana. Journal of public health in Africa, 2016. 7 (2).

[21] Frambo, A. A. B., et al., Prevalence of HBsAg and knowledge about hepatitis B in pregnancy in the Buea Health District, Cameroon: a cross-sectional study. BMC research notes, 2014. 7 (1): p. 394.

[22] Yakasai, I. A., et al., Sero-prevalence of hepatitis B virus infection and its risk factors among pregnant women attending antenatal clinic at Aminu Kano Teaching Hospital, Kano, Nigeria. Journal of Basic and Clinical Reproductive Sciences, 2012. 1 (1-2): p. 49-55.

[23] Kirbak, A. L. S., Seroprevalence for Hepatitis B virus among pregnant women attending antenatal clinic in Juba Teaching Hospital, Republic of South Sudan. The Pan African medical journal, 2017. 26 .

[24] Pereira, L. M., et al., Population-based multicentric survey of hepatitis $B$ infection and risk factor differences among the three regions in Brazil. The American journal of tropical medicine and hygiene, 2009. 81 (2): p. 240-247.

[25] Vázquez-Martínez, J. L., et al., Seroprevalence de hepatitis $B$ en mujeres embarazadas en México. Salud Pública de México, 2003. 45 (3): p. 165-170.

[26] Bani, I., et al., Prevalence and risk factors of hepatitis $B$ virus among pregnant women in Jazan Region-Kingdom of Saudi Arabia. J Biol Agric Healthcare, 2012. 2 (8).

[27] Onwuakor, C., et al., Sero-prevalence of hepatitis B surface antigen (HBsAg) amongst pregnant women attending antenatal clinic at the Federal Medical Centre Umuahia, Abia State, Nigeria. Am J Public Health Res, 2014. 2 (6): p. 255259.

[28] Kasper, D. and T. R. Harrison, Harrison's principles of internal medicine. Vol. 1. 2005: McGraw-Hill, Medical Publishing Division.

[29] Tiruneh, M., Seroprevalence of multiple sexually transmitted infections among antenatal clinic attendees in Gondar Health Center, northwest Ethiopia. Ethiopian medical journal, 2008. 46 (4): p. 359-366. 